\title{
LSD1 Inhibitor GSK2879552
}

National Cancer Institute

\section{Source}

National Cancer Institute. LSD1 Inhibitor GSK2879552. NCI Thesaurus. Code C113646.

An orally available, irreversible, inhibitor of lysine specific demethylase 1 (LSD1), with potential antineoplastic activity. Upon administration, GSK2879552 binds to and inhibits LSD1, a demethylase that suppresses the expression of target genes by converting the dimethylated form of lysine at position 4 of histone $\mathrm{H} 3$ (H3K4) to mono- and unmethylated H3K4. LSD1 inhibition enhances H3K4 methylation and increases the expression of tumor-suppressor genes. This may lead to an inhibition of cell growth in LSD1-overexpressing tumor cells. LSD1, overexpressed in certain tumor cells, plays a key role in tumor cell growth and survival. 